\title{
PERFORMANSI PURIFIKASI BIOGAS DENGAN KOH BASED ABSORBENT
}

\author{
Dadang Hermawan, Nurkholis Hamidi, Mega Nur Sasongko \\ Teknik Mesin Universitas Brawijaya Malang, MT Haryono 167, Malang 65145, Indonesia \\ Phone : +62-341-587710, Fax : +62-341-551430 \\ E-mail: dang_gama@yahoo.com
}

\begin{abstract}
The absorpstion of $\mathrm{CO}_{2}$ is aimed to increase the methane gas fraction in biogas. Enhancing methane fraction hopefully will increase the total energy of the biogas it self. The purification process of biogas minimizing another elements maintains combustion, especially minimizing $\mathrm{H}_{2} \mathrm{O}$, $\mathrm{CO}_{2}$, and $\mathrm{H}_{2} \mathrm{~S}$. The purification using $\mathrm{KOH}$ as the absorbent to decrease the $\mathrm{CO}_{2}$. The result shown that the content of $\mathrm{CO}_{2}$ decreased into $27 \%$ from $35.5 \%$, the average content of $\mathrm{CH}_{4}$ increased from $18 \%$ to $48.5 \%$. Increasing $\mathrm{KOH}$ composition decreases bubble generator diameter and mass flow.
\end{abstract}

Keywords: Biogas, Debit, Long Live Bubble, Composition KOH solution, and Diameter Bubble

\section{PENDAHULUAN}

Penggunaan energi terbarukan yang banyak dikembangkan saat ini berasal dari limbah organik seperti kotoran hewan, sampah biomassa, kotoran manusia, dan limbah tahu yang dapat dimanfaatkan melalui proses anaerobic digestion sehingga dihasilkan sebuah bahan bakar terbaru yaitu biogas. Pembuatan biogas mempunyai prinsip kerja yaitu memanfaatkan proses pencernaan yang dilakukan oleh bakteri methanogen sehingga menghasilkan kandungan metana $\left(\mathrm{CH}_{4}\right)$ yang terdapat dalam biogas. Biogas mempunyai komposisi kandungan gas yang terdiri dari metana $\left(\mathrm{CH}_{4}\right)$ sekitar $50-70 \%$, untuk karbondioksida $\left(\mathrm{CO}_{2}\right)$ sekitar $30-40 \%$, untuk hidrogen $\left(\mathrm{H}_{2}\right)$, nitrogen $\left(\mathrm{N}_{2}\right)$, uap air $\left(\mathrm{H}_{2} \mathrm{O}\right)$ dan belerang $\left(\mathrm{H}_{2} \mathrm{~S}\right)$ cenderung lebih kecil prosentasinya [1].

Kualitas biogas yang dihasilkan dari beberapa macam limbah kotoran ternak maupun sampah masih kurang baik dikarenakan masih banyaknya zat pengotor atau (impurity) yang terdapat dala biogas. Kandungan zat pengotor pada air yang berasal dari biogas karena adanya reaksi dengan $\mathrm{H}_{2} \mathrm{~S}$, $\mathrm{NH}_{3}$ dan $\mathrm{CO}_{2}$ dapat menimbulkan korosi dalam kompresor, tangki penyimpanan gas dan mesin. Hal ini dikarenakan $\mathrm{CO}_{2} a k a n$ membentuk asam jika berinterkasi dengan $\mathrm{H}_{2} \mathrm{O}$ dan nilai kalor dari biogas akan rendah, sedangkan kandungan $\mathrm{H}_{2} \mathrm{~S}$ akan menimbulkan korosi dalam kompresor, tangki penyimpanan gas dan mesin [2]. Upaya untuk meningkatkan kualitas biogas dari zat pengotor perlu dilakukan proses purifikasi atau pemurnian pada biogas dengan menyerap atau mengurangi kandungan zat pengotor pada biogas tersebut. Proses pemurnian biogas yang sudah beberapa dilakukan adalah mengurangi zat pengotor yang merupakan salah satu kandungan yang terdapat pada biogas yaitu gas karbon dioksida $\left(\mathrm{CO}_{2}\right)$.

Untuk penggunaan fliuda air dalam proses penyerapan dapat menurunkan kadar $\mathrm{CO}_{2}$ dalam biogas. Menurut Arai (Anonim, 2010), konsentrasi dari larutan penyerap merupakan salah satu faktor yang dapat mempengaruhi absorbsi, semakin tinggi konsentrasi larutan penyerap yang digunakan pada penyerapan $\mathrm{CO}_{2}$, maka penyerapan $\mathrm{CO}_{2}$ akan semakin maksimal.

Untuk mengurangi kadar $\mathrm{CO}_{2}$ yang terkandung dalam biogas adalah dengan mengabsorbsi $\mathrm{CO}_{2}$ menggunakan larutan $\mathrm{NaOH}$ secara kontinyu dalam suatu reaktor (absorber). Pada penelitian ini[3] variabel yang diteliti adalah pengaruh laju alir $\mathrm{NaOH}$ terhadap $\mathrm{CO}_{2}$ yang terserap dan $\mathrm{CH}_{4}$ yang dihasilkan. Absorbsi $\mathrm{CO}_{2}$ dilakukan dengan mengumpankan larutan $\mathrm{NaOH}$ secara kontinyu pada bagian atas menara pada konsentrasi dan laju alir tertentu, sementara biogas dialirkan pada bagian bawah menara. Dari hasil analisa dan perhitungan didapatkan jumlah $\mathrm{CO}_{2}$ yang terserap dan $\mathrm{CH}_{4}$ yang dihasilkan semakin besar seiring berkurangnya laju alir $\mathrm{NaOH}$ serta 
$\% \mathrm{CO}_{2}$ yang terserap maksimum $58,11 \%$ dan kadar $\mathrm{CH}_{4}$ yang dihasilkan sebesar $74,13 \%$.

Pada penelitian adsorpsi $\mathrm{CO}_{2}$ menggunakan zeolit [4]diperoleh bahwakonsentrasi, laju alir dan berat zeolit berpengaruh pada proses adsorpsi $\mathrm{CO}_{2}$. Proses adsorpsi $\mathrm{CO}_{2}$ dilakukan pada temperatur $31^{\circ} \mathrm{C}$, tekanan 1 atm dengan proses kontinyu selama 60 menit dan menghasilkan konsentrasi $\mathrm{CO}_{2} \quad 19,71 \% \mathrm{~mol}$ dan laju alir $\mathrm{CO}_{2}\left(1 /\right.$ menit), zeolit menyerap $\mathrm{CO}_{2}$ sebanyak $0,00156 \%$ mol dan diperoleh konstanta kecepatan adsorpsi (k) 0,008. Lebih lanjut dilakukan aplikasi untuk pemurnian biogas, proses ini menghasilkan bahwa zeolit zeochem dapat digunakan untuk menurunkan kadar $\mathrm{CO}_{2}$ sebanyak $18,70 \%$ sehingga kemurnian $\mathrm{CH}_{4}$ meningkat sebanyak 30,4\%. Proses pemurnian biogas dilakukan karena didalam biogas masih terkandung unsur-unsur yang tidak bermanfaat untuk pembakaran khususnya $\mathrm{H}_{2} \mathrm{O}, \mathrm{CO}_{2}$ dan $\mathrm{H}_{2} \mathrm{~S}$ dan senyawa lainnya. Pemurnian gas $\mathrm{CO}_{2}$ didalam biogasdilakukan dengan teknik absorbsi menggunakan absorben berupa $\mathrm{Ca}(\mathrm{OH})_{2}$ dan $\mathrm{NaOH}$.

\section{Biogas}

Biogas atau gas bio merupakan salah satu jenis energi yang dapat dibuat dari banyak bahan buangan dan bahan sisa, semacam sampah, kotoran ternak, jerami, enceng gondok serta banyak bahan-bahan lainnya lagi. Segala jenis bahan yang dalam istilah kimia termasuk senyawa organik, entah berasal dari sisa dan kotoran hewan ataupun sisa tanaman, dapat dijadikan bahan biogas [5]. Biogas memiliki beberapa keunggulan dibandingkan bahan bakar fosil sehingga layak untuk dipertimbangkan sebagai pilihan energi bagi masyarakat. Sifatnya yang dapat diperbaharui dan ramah lingkungan merupakan keunggulan yang dimiliki biogas dibandingkan dengan bahan bakar fosil.

Kandungan biogas didominasi oleh gas metana $\left(\mathrm{CH}_{4}\right)$ kemudian disusul oleh karbondioksida. Dimana diketahui $\mathrm{CO}_{2}$ merupakan sisa hasil dari suatu pembakaran maka akan menggangu proses pembakaran itu sendiri, hal ini menyebabkan panas yang dihasilkan masih rendah sehingga kualitas nyala api biogas masih belum optimum. Oleh karena itu dibutuhkan usaha untuk menurunkan kadar $\mathrm{CO}_{2}$ yang diharapkan dapat meningkatkan kualitas dari biogas itu sendiri [6]. Adapun proses usaha untuk menurunkan kadar $\mathrm{CO}_{2}$ salah satunya adalah proses absorbsi.

Absorbsi adalah pemisahan suatu gas tertentu dari campuran gas-gasdengan cara pemindahan massa ke dalam suatu liquid. Hal ini dilakukan dengancaramengantarkan aliran gas dengan liquid yang mempunyai selektivitas pelarut yang berbeda dari gas yang akan dipisahkannya [7]. Untuk absorbsi kimia, transfer massa dilakukan dengan bantuan reaksi kimia. Suatu pelarut kimia yang berfungsi sebagai absorben akan bereaksidengan gas asam $\left(\mathrm{CO}_{2}\right.$ dan $\left.\mathrm{H}_{2} \mathrm{~S}\right)$ menjadi senyawa lain, sehingga gas alam yangdihasilkan sudah tidak lagi mengandung gas asam yang biasanya akan mencemari lingkungan apabila ikut terbakar.

\section{Reaksi Larutan $\mathrm{KOH}$ dan $\mathrm{CO}_{2}$}

Fungsi dari Kristal $\mathrm{KOH}$ pada penelitian ini yaitu sebagai pengikat $\mathrm{CO}_{2}$. Kristal $\mathrm{KOH}$ dapat mengikat $\mathrm{CO}_{2}$ karena bersifat higroskopis. Reaksi antara $\mathrm{KOH}$ dengan $\mathrm{CO}_{2}$, sebagai berikut:

$$
\begin{aligned}
& \mathrm{KOH}+\mathrm{CO}_{2} \rightarrow \mathrm{KHCO}_{3} \\
& \mathrm{KHCO}_{3}+\mathrm{KOH} \rightarrow \mathrm{K}_{2} \mathrm{CO}_{3}+\mathrm{H}_{2} \mathrm{O}
\end{aligned}
$$

Absorbsi di atas merupakan reaksi yang terjadi secara kimia, dikarenakan terjadinya reaksi kimia secara langsung antara $\mathrm{CO}_{2}$ dengan larutan $\mathrm{KOH}$. Pada proses ini, kondisi pada fase gas serupa dengan absorbsi fisik. Tetapi pada fase cair, selain terdapat lapisan tipis cairan juga terdapat zona reaksi. Reaksi kimia yang terjadi adalah irreversible, dimana $\mathrm{CO}_{2}$ pada fase gas akan diabsorbsi oleh larutan $\mathrm{KOH}$ pada fase cair. Pada saat gas mendekati interfase cair, gas $\mathrm{CO}_{2}$ akan larut dan langsung bereaksi dengan larutan $\mathrm{KOH}$.

\section{METODE PENELITIAN}

Perencanaan instalasi penelitian untuk purifikasi biogas ditampilkan pada Gambar 1 . Alat ini bekerja untuk mengikat kotoran yang terdapat pada biogas yaitu salah satunya berupa $\mathrm{CO}_{2}$ yang merupakan zatpengotor dan meningkatkan prosentase $\mathrm{CH}_{4}$ yang terdapat pada biogas. Adapun instalasi penelitian untuk purifikasi biogas ini terdiri dari beberapa peralatan pendukung diantaranya terdapat 
tabung gas yang digunakan untuk menampung gas seperti $\mathrm{CO}_{2}, \mathrm{CH}_{4}$ murni dan biogas sebagai obyek yang diteliti. Alat pendukung lainnya adalah kompresor yang digunakan untuk membantu aliran gas sesuai dengan tekanan yang ditentukan dikarenakan untuk biogas tekanan yang dihasilkan kecil sehingga dapat membantu biogas mengalir melewati larutan $\mathrm{KOH}$.

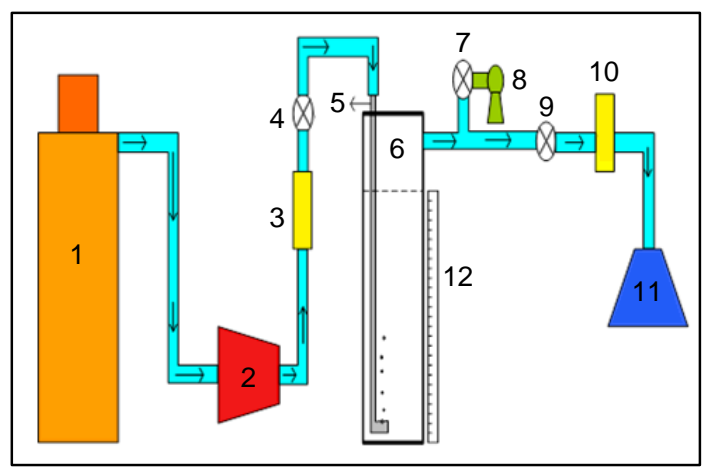

Keterangan:
1. Tabung biogas
2. Kompresor
3. Manometer grid
4. Katup
5. Saluran pipa
7. Katup
8. Vacuum pump
9. Katup
10. Manometer grid
11. Gas bag
6. Bejana untuk larutan $\mathrm{KOH}$ 12. Alat ukur ketinggian

Gambar 1. Instalasi penelitian untuk purifikasi biogas

Dalam instalasi penelitian ini dipasangkan manometer grid pada saluran pipa yang dialiri gas untuk mengetahui perbedaan ketinggian aliran gas yang melewati manometer grid ini guna didapatkan laju aliran gas. Manometer grid ini dipasang sebelum bejana (berisi larutan $\mathrm{KOH}$ ) dan sesudah melewati bejana (larutan $\mathrm{KOH})$. Sebelum gas melewati bejana tersebut pada saluran pipa juga dipasang katup (valve) untuk membuka dan menutup aliran gas yang akan masuk dalam bejana dan gas yang keluar dari bejana sebelum ditampung dalam gas bag. Pada saluran pipa ini juga dipasang pipa yang diberikan lubang-lubang sesuai diameter yang direncanakan untuk menghasilkan gas bubble generator yang ditempatkan didalam bejana (larutan $\mathrm{KOH}$ ).

Peralatan penunjang lainnya pada instalasi ini adalah bejana sebagai tempat campuran antara $\mathrm{KOH}$ dan $\mathrm{H}_{2} \mathrm{O}$ (aquades) sesuai dengan konsentrasi yang ditentukan dalam pengujian. Untuk mengukur ketinggian
Larutan $\mathrm{KOH}$ maka dipasangkan alat ukur ketinggian pada bejana sesuai dengan tinggi larutan yang direncanakan. Pada bejana yang telah diisi dengan larutan $\mathrm{KOH}$ sesuai dengan tinggi larutan masih tersisa ruang kosong yang masih terdapat udara dan kondisinya harus vakum. Untuk itu perlu divakumkan dengan menggunakan vacuum pump. Hasil dari pengujian gas yang telah melewati saluran keluar ditampung dalam gas bag. Gas dalam gas bag ini dilakukan pengujian kandungan yang terdapat dalam gas tersebut dengan menggunakan gas chromatography.

Untuk mendapatkan data penelitian menggunakan gas $\mathrm{CO}_{2}, \mathrm{CH}_{4}$ murni dan biogas maka langkah-langkah yang dilakukan adalah dengan mempersiapkan semua peralatan yang diperlukan. Selanjutnya mencampur larutan kimia antara $\mathrm{KOH}+\mathrm{H}_{2} \mathrm{O}$ (aquades) sesuai dengan kadar yang diinginkan dan sesuai dengan tinggi larutan yang ditentukan dengan melihat alat ukur ketinggian yang dipasang dalam bejana tersebut. Larutan yang sudah tercampur dimasukkan di wadah penampung larutan (bejana). Pipa dengan lubang-lubang untuk mendapatkan bubble generator dari aliran gas dimasukkan pada bejana yang berisi larutan $\mathrm{KOH}$. Penutup bejana dipasangkan dengan memberikan seal agar tidak terjadi kebocoran saat pengujian dan pasang vacuum pump pada saluran keluar, kemudian vacuum pumpdiaktifkan untuk membuat kondisi diatas larutan $\mathrm{KOH}$ yang tersisa pada kondisi vacuum sebelum dilakukan pemasukan gas yang direncanakan. Selanjutnya kondisi gas dalam tabung gas dan kompresor dipastikan sudah terisi dan tekanan yang dikeluarkan stabil.

Langkah berikutnya katup (valve) dibuka untuk gas yang sudah direncanakan pada kecepatan aliran tertentu. Gas yang mengalir dapat dilihat perbedaan ketinggian pada alat ukur manometer grid yang dipasang sebelum masuk dalam bejana (larutan $\mathrm{KOH}$ ) dan sesudah melewati bejana (larutan $\mathrm{KOH}$ ). Kemudian gas yang sudah keluar ditampung dalam gas bag. Gas yang berada dalam gas bagdiuji dengan alat gas chromatography untuk mengetahui prosentasi kandungan gas sebelum melewati larutan $\mathrm{KOH}$ dan setelah melewati larutan $\mathrm{KOH}$.Prosedur yang sama dilakukan menggunakan beberapa gas ( $\mathrm{CO}_{2}$ murni, $\mathrm{CH}_{4}$ murni dan biogas) dengan variable yang ditentukan diantaranya 
penggunaan variasi konsentrasi $\mathrm{KOH}$ yaitu $\mathrm{KOH} 0,99 \%$, $1,47 \%$, dan $1,96 \%$ dan variasi lubang pada bubble generator yang digunakan dengan diamater $1 \mathrm{~mm} ; 0,8 \mathrm{~mm} ; 0,5 \mathrm{~mm}$. Data yang sudah dihasilkan setelah itu menghubungkan semua data dengan rumus dan membuat grafik.

\section{HASIL DAN PEMBAHASAN}

Hubungan lama tinggal bubble terhadap debit terikat $\mathrm{CO}_{2}$ murni dan $\mathrm{CH}_{4}$ murni pada variasi konsentrasi $\mathrm{KOH}$

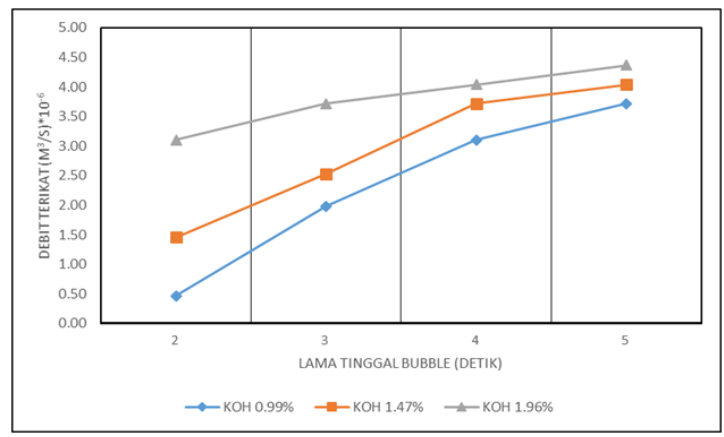

Gambar 2. Grafik hubungan lama tinggal bubble terhadap debit terikat $\mathrm{CO}_{2}$ pada variasi konsentrasi $\mathrm{KOH}$

Dari Gambar 2 diatas didapatkan hasil perhitungan untuk mendapatkan debit terikat untuk masing-masing variasi konsentrasi $\mathrm{KOH}$ terhadap lama tinggal bubble. Dapat diketahui untuk konsentrasi $\mathrm{KOH} 0.99 \%$ dan lama tinggal bubble 2 detik, debit terikat yang dihasilkan sebesar $0.47 \times 10^{6} \mathrm{~m}^{3} / \mathrm{s}$. Sedangkan untuk lama tinggal bubble 3 detik, debit terikat yang dihasilkan sebesar $1.98 \times 10^{6} \mathrm{~m}^{3} / \mathrm{s}$. Untuk lama tinggal bubble 4 detik, debit terikatnya yang dihasilkan sebesar $3.11 \times 10^{6} \mathrm{~m}^{3} / \mathrm{s}$. Untuk lama tinggal bubble 5 detik, debit terikatnya yang dihasilkan sebesar $3.72 \times 10^{6} \mathrm{~m}^{3} / \mathrm{s}$.

Untuk konsentrasi $\mathrm{KOH} 1.47 \%$ dan $1.96 \%$ dari grafik diatas, dapat diketahui juga untuk debit terikatnya semakin meningkat terhadap lama tinggal bubble. Oleh karena itu untuk proses penyerapan $\mathrm{CO}_{2}$ pada larutan $\mathrm{KOH}$ dapat diketahui bahwa semakin tinggi konsentrasi $\mathrm{KOH}$ maka semakin besar debit terikat yang dihasilkan. Begitu juga semakin lama tinggal bubble maka semakin besar juga debit terikat yang dihasilkan. Dalam penelitian ini diketahui bahwa konsentrasi $\mathrm{KOH} 1.96 \%$ dan lama tinggal bubble 5 detik proses penyerapan $\mathrm{CO}_{2}$ murni oleh larutan $\mathrm{KOH}$ lebih baik, hal ini dapat diketahui debit terikat yang dihasilkan paling tinggi yaitu sebesar $4.37 \times 10$ ${ }^{6} \mathrm{~m}^{3} / \mathrm{s}$.

Dari hasil pengambilan data untuk hubungan lama tinggal bubble terhadap debit terikat $\mathrm{CH}_{4}$ murni pada variasi konsentrasi $\mathrm{KOH}$ bahwa untuk kecepatan aliran gas $\mathrm{CH}_{4}$ murni pada saat masuk dan keluar besarannya sama maka dapat diketahui debit masuk dan debit keluar mempunyai besaran yang sama pula, sehingga dapat diketahui debit terikat gas $\mathrm{CH}_{4}$ murni dari proses pengurangan antara debit masuk dikurangi debit keluar dari gas $\mathrm{ch}_{4}$ murni sebesar $0 \mathrm{~m}^{3} / \mathrm{s}$. Hal ini dapat diketahui bahwa tidak terjadi proses penyerapan gas $\mathrm{CH}_{4}$ didalam larutan $\mathrm{KOH}$.

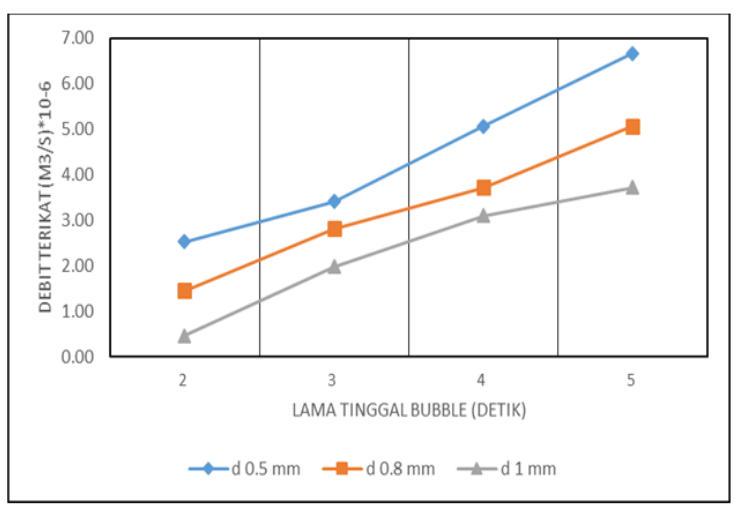

Gambar 3. Grafik hubungan lama tinggal bubble terhadap debit terikat $\mathrm{CO}_{2}$ pada variasi lubang bubble generator

Hubungan lama tinggal bubble terhadap debit terikat $\mathrm{CO}_{2}$ murni pada variasi lubang bubble generator ditampilkan pada Gambar 3. Dalam penelitian ini untuk dapat diketahui untuk lubang bubble generator $0.5 \mathrm{~mm}$ dan lama tinggal bubble5 detik, debit terikat yang dihasilkan sebesar $13.20 \times 10^{-6} \mathrm{~m}^{3} / \mathrm{s}$. Sedangkan untuk lama tinggal bubble 4 detik, debit terikat yang dihasilkan sebesar $10.03 \times 10^{-}$ ${ }^{6} \mathrm{~m}^{3} / \mathrm{s}$. Untuk lama tinggal bubble 3 detik, debit terikatnya yang dihasilkan sebesar $6.75 \times 10^{-6}$ $\mathrm{m}^{3} / \mathrm{s}$. Untuk lama tinggal bubble 2 detik, debit terikatnya yang dihasilkan sebesar $5.01 \times 10^{-6}$ $\mathrm{m}^{3} / \mathrm{s}$. Untuk lubang bubble generator $0.8 \mathrm{~mm}$ dan $1 \mathrm{~mm}$ dari grafik diatas, dapat diketahui juga untuk debit terikatnya semakin meningkat terhadap lama tinggal bubble .

Oleh karena itu untuk proses penyerapan $\mathrm{CO}_{2}$ pada larutan $\mathrm{KOH}$ dapat diketahui bahwa 
semakin kecil diameter lubang bubble generator maka semakin besar debit terikat yang dihasilkan. Begitu juga semakin lama tinggal bubble maka semakin besar juga debit terikat yang dihasilkan. Dalam penelitian ini diketahui bahwa lubang bubble generator untuk $\mathrm{d}=0.5 \mathrm{~mm}$ dan lama tinggal bubble 5 detik proses penyerapan $\mathrm{CO}_{2}$ murni oleh larutan $\mathrm{KOH}$ lebih baik, hal ini dapat diketahui debit terikat yang dihasilkan paling tinggi yaitu sebesar $13.20 \times 10^{-6} \mathrm{~m}^{3} / \mathrm{s}$.

Dari hasil pengambilan data untuk Hubungan lama tinggal bubble terhadap debit terikat $\mathrm{CH}_{4}$ murni pada variasi lubang bubble generator bahwa untuk kecepatan aliran gas $\mathrm{CH}_{4}$ murni pada saat masuk dan keluar besarannya sama maka debit terikat gas $\mathrm{CH}_{4}$ murni dari proses pengurangan antara debit masuk dikurangi debit keluar dari gas $\mathrm{CH}_{4}$ murni sebesar $0 \mathrm{~m}^{3} / \mathrm{s}$. Hal ini dapat diketahui bahwa tidak terjadi proses penyerapan gas $\mathrm{CH}_{4}$ didalam larutan $\mathrm{KOH}$.

Hubungan debit masuk terhadap debit terikat
$\mathrm{CO}_{2}$ murni pada variasi konsentrasi $\mathrm{KOH}$

Dalam penelitian ini untuk mengetahui salah satu performansi dari proses penyerapan $\mathrm{CO}_{2}$ dalam larutan $\mathrm{KOH}$ adalah dengan mengetahui variasi debit masuk dengan variasi $\mathrm{KOH} 0.99 \%, \mathrm{KOH} 1.47 \%$ dan $\mathrm{KOH} 1.96 \%$ terhadap diameter lubang bubble generator yang digunakan $(\mathrm{d}=1 \mathrm{~mm}$ ) dan tinggi larutan $\mathrm{KOH}$ diantaranya $1.2 \mathrm{~m}$. Hubungan debit masuk terhadap debit terikat $\mathrm{CO}_{2}$ murni pada variasi konsentrasi KOH ditampilkan pada Gambar 4.

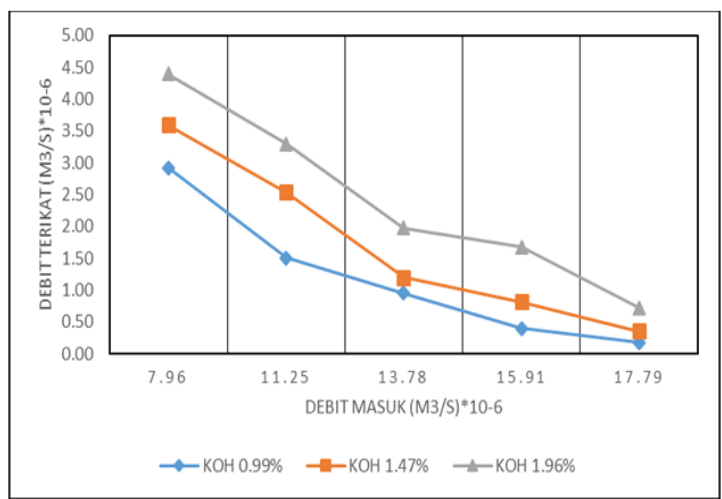

Gambar 4. Grafik hubungan debit masuk terhadap debit terikat $\mathrm{CO}_{2}$ murni pada variasi konsentrasi $\mathrm{KOH}$
Dapat diketahui untuk konsentrasi $\mathrm{KOH}$ $0.99 \%$ dan debit masuk $7.96 \times 10^{-6} \mathrm{~m}^{3} / \mathrm{s}$, debit terikat yang dihasilkan sebesar $2.92 \times 10^{-6} \mathrm{~m}^{3} / \mathrm{s}$. Sedangkan untuk debit masuk $11.25 \times 10^{-6}$ $\mathrm{m}^{3} / \mathrm{s}$, debit terikat yang dihasilkan sebesar 1.51 $x \times 10^{-6} \mathrm{~m}^{3} / \mathrm{s}$. Untuk debit masuk $13.78 \times \times 10^{-6}$ $\mathrm{m}^{3} / \mathrm{s}$, debit terikatnya yang dihasilkan sebesar $0.95 \times 10^{-9} \mathrm{~m}^{3} / \mathrm{h}$. Untuk debit masuk $15.91 \times 10^{-}$ ${ }^{6} \mathrm{~m}^{3} / \mathrm{s}$, debit terikatnya yang dihasilkan sebesar $0.40 \times 10^{-6} \mathrm{~m}^{3} / \mathrm{s}$. Untuk debit masuk $17.79 \times 10^{-}$ ${ }^{6} \mathrm{~m}^{3} / \mathrm{s}$, debit terikatnya yang dihasilkan sebesar $0.18 \times 10^{-6} \mathrm{~m}^{3} / \mathrm{s}$.

Untuk konsentrasi $\mathrm{KOH} 1.47 \%$ dan $1.96 \%$ dari grafik diatas, dapat diketahui juga untuk debit masuk semakin besar maka debit terikatnya semakin kecil. Oleh karena itu untuk proses penyerapan $\mathrm{CO}_{2}$ pada larutan $\mathrm{KOH}$ dapat diketahui bahwa semakin tinggi konsentrasi $\mathrm{KOH}$ maka semakin besar debit terikat yang dihasilkan. Begitu juga semakin tinggi debit masuk maka semakin kecil debit terikat yang dihasilkan. Dalam penelitian ini diketahui bahwa konsentrasi $\mathrm{KOH} 1.96 \%$ dan debit masuk $7.96 \times 10^{-6} \mathrm{~m}^{3} / \mathrm{s}$ proses penyerapan $\mathrm{CO}_{2}$ murni oleh larutan $\mathrm{KOH}$ lebih baik, hal ini dapat diketahui debit terikat yang dihasilkan paling tinggi yaitu sebesar $4.40 \times 10^{-}$ $6 \mathrm{~m}^{3} / \mathrm{s}$.

Sedangkan untuk penelitian pada $\mathrm{CH}_{4}$ murni pada variasi debit masuk bahwa untuk kecepatan aliran gas $\mathrm{CH}_{4}$ murni pada saat masuk dan keluar besarannya sama maka dapat diketahui debit masuk dan debit keluar mempunyai besaran yang sama pula, sehingga dapat diketahui debit terikat gas $\mathrm{CH}_{4}$ murni dari proses pengurangan antara Debit masuk dikurangi debit keluar dari gas $\mathrm{CH}_{4}$ murni sebesar $0 \mathrm{~m}^{3} / \mathrm{h}$. Hal ini dapat diketahui bahwa tidak terjadi proses penyerapan gas $\mathrm{CH}_{4}$ didalam larutan $\mathrm{KOH}$.

Hubungan debit masuk terhadap prosentase debit terikat $\mathrm{CO}_{2}$ murni pada variasi bubble generator

Dalam penelitian ini untuk mengetahui performansi dari proses penyerapan $\mathrm{CO}_{2}$ dalam larutan $\mathrm{KOH}$ adalah dengan mengetahui variasi debit masuk terhadap diameter lubang bubble generator d $0.5 \mathrm{~mm}$, d $0.8 \mathrm{~mm}$, d $1 \mathrm{~mm}$ dan konsentrasi larutan $\mathrm{KOH} 0.99 \%$ dan tinggi larutan $\mathrm{KOH}$ diantaranya $1.2 \mathrm{~m}$. Dari grafik pada Gambar 5 dapat diketahui untuk lubang bubble generator d $0.5 \mathrm{~mm}$, debit masuk $7.96 \mathrm{x}$ 
$10^{-6} \mathrm{~m}^{3} / \mathrm{s}$, debit terikat yang dihasilkan sebesar $4.58 \times 10^{-6} \mathrm{~m}^{3} / \mathrm{s}$. Sedangkan untuk debit masuk $11.25 \times 10^{-6} \mathrm{~m}^{3} / \mathrm{s}$, debit terikat yang dihasilkan sebesar $2.54 \times \times 10^{-6} \mathrm{~m}^{3} / \mathrm{s}$. Untuk debit masuk $13.78 \times \times 10^{-6} \mathrm{~m}^{3} / \mathrm{s}$, debit terikatnya yang dihasilkan sebesar $2.53 \times 10^{-9} \mathrm{~m}^{3} / \mathrm{h}$. Untuk debit masuk $15.91 \times 10^{-6} \mathrm{~m}^{3} / \mathrm{s}$, debit terikatnya yang dihasilkan sebesar $1.24 \times 10^{-6} \mathrm{~m}^{3} / \mathrm{s}$. Untuk debit masuk $17.79 \times 10^{-6} \mathrm{~m}^{3} / \mathrm{s}$, debit terikatnya yang dihasilkan sebesar $0.40 \times 10^{-6} \mathrm{~m}^{3} / \mathrm{s}$.

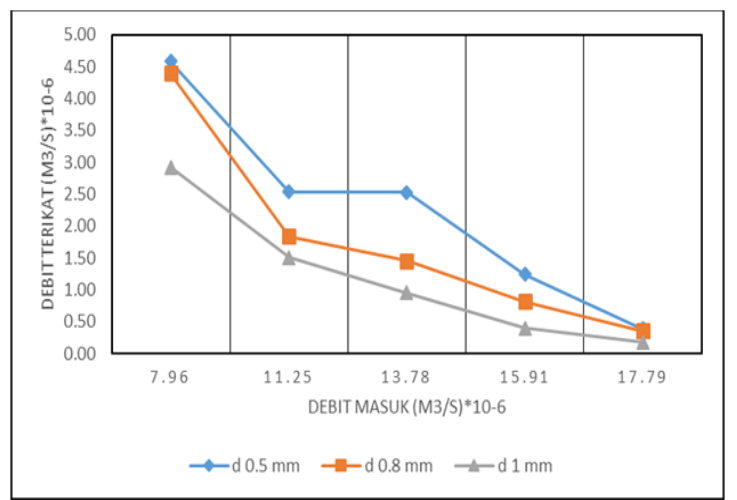

Gambar 5. Grafik hubungan debit masuk terhadap debit terikat $\mathrm{CO}_{2}$ murni pada variasi lubang bubble generator

Untuk lubang bubble generator d $0.8 \mathrm{~mm}$ dan $\mathrm{d} 1 \mathrm{~mm}$ dari grafik diatas, dapat diketahui juga untuk debit masuk semakin besar maka debit terikatnya semakin kecil. Oleh karena itu untuk proses penyerapan $\mathrm{CO}_{2}$ pada larutan $\mathrm{KOH}$ dapat diketahui bahwa semakin kecil diameter lubang bubble generator maka semakin besar debit terikat yang dihasilkan. Begitu juga semakin tinggi debit masuk maka semakin kecil debit terikat yang dihasilkan. Dalam penelitian ini diketahui bahwa lubang bubble generator d $0.5 \mathrm{~mm}$ dan debit masuk $7.96 \times 10^{-6} \mathrm{~m}^{3} / \mathrm{s}$ proses penyerapan $\mathrm{CO}_{2}$ murni oleh larutan $\mathrm{KOH}$ lebih baik, hal ini dapat diketahui debit terikat yang dihasilkan paling tinggi yaitu sebesar $4.58 \times 10^{-6} \mathrm{~m}^{3} / \mathrm{s}$.

Hubungan lama tinggal bubble terhadap prosentase $\mathrm{CO}_{2}$ dan $\mathrm{CH}_{4}$ pada biogas dengan variasi konsentrasi $\mathrm{KOH}$

Dari grafik pada Gambar 6 diketahui untuk konsentrasi $\mathrm{KOH} \quad 0.99 \%$ dan lama tinggal bubble1 detik, prosentase $\mathrm{CO}_{2}$ yang dihasilkan sebesar $20 \%$ dan $\mathrm{CH}_{4}$ yang dihasilkan sebesar $48.5 \%$. Sedangkan untuk lama tinggal bubble 2 detik, prosentase $\mathrm{CO}_{2}$ yang dihasilkan sebesar
$17 \%$ dan $\mathrm{CH}_{4} 56 \%$. Untuk lama tinggal bubble 3 detik, prosentase $\mathrm{CO}_{2}$ yang dihasilkan sebesar $15.5 \%$ dan $\mathrm{CH}_{4}$ 57\%. Untuk lama tinggal bubble 4 detik, prosentase $\mathrm{CO}_{2}$ yang dihasilkan sebesar $13 \%$ dan $\mathrm{CH}_{4} 61 \%$. Untuk lama tinggal bubble 5 detik, prosentase $\mathrm{CO}_{2}$ yang dihasilkan sebesar $10 \%$ dan $\mathrm{CH}_{4} 64 \%$.

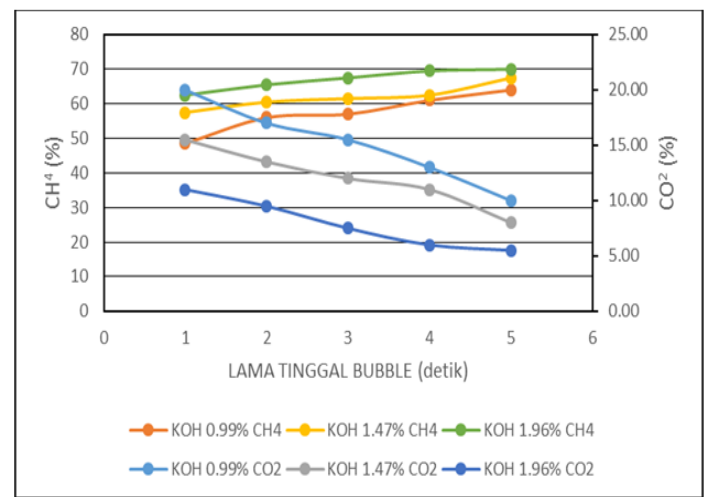

Gambar 6. Grafik hubungan lama tinggal bubble terhadap prosentase $\mathrm{CO}_{2}$ dan $\mathrm{CH}_{4}$ pada biogas dengan variasi konsentrasi $\mathrm{KOH}$

Untuk konsentrasi $\mathrm{KOH} 1.47 \%$ dan $1.96 \%$ dari grafik diatas, dapat diketahui juga semakin lama tinggal bubble prosentase $\mathrm{CO} 2$ yang dihasilkan semakin kecil dan semakin tinggi larutan prosentase $\mathrm{CH}_{4}$ semakin meningkat. Oleh karena itu prosentase $\mathrm{CO}_{2}$ dalam biogas setelah dilakukan pengujian untuk variasi konsentrasi $\mathrm{KOH}$, semakin tinggi konsentrasi $\mathrm{KOH}$ maka prosentase $\mathrm{CO}_{2}$ semakin kecil sedangkan untuk prosentase $\mathrm{CH}_{4}$ semakin meningkat. Dalam penelitian ini diketahui bahwa konsentrasi $\mathrm{KOH} 1.96 \%$ dan lama tinggal bubble 5 detik didapatkan hasil yang lebih baik, hal ini didapatkan prosentase $\mathrm{CO}_{2}$ paling kecil adalah $5.5 \%$ dan untuk prosentase $\mathrm{CH}_{4}$ paling besar adalah $70 \%$.

Hubungan lama tinggal bubble terhadap prosentase $\mathrm{CO}_{2}$ dan $\mathrm{CH}_{4}$ pada biogas dengan variasi lubang bubble generator

Dari grafik pada Gambar 7 didapatkan bahwa untuk diameter lubang bubble generator $0.5 \mathrm{~mm}$ dan lama tinggal bubble 1 detik, prosentase $\mathrm{CO}_{2}$ yang dihasilkan sebesar $11.5 \%$ dan $\mathrm{CH}_{4} 62 \%$. Sedangkan untuk lama tinggal bubble 2 detik, prosentase $\mathrm{CO}_{2}$ yang dihasilkan sebesar $10.5 \%$ dan $\mathrm{CH}_{4} 63 \%$. Untuk lama tinggal bubble 3 detik, prosentase $\mathrm{CO}_{2}$ yang dihasilkan sebesar $9.5 \%$ dan $\mathrm{CH}_{4} \quad 65.5 \%$. 
Untuklama tinggal bubble 4 detik, prosentase $\mathrm{CO}_{2}$ yang dihasilkan sebesar $9 \%$ dan $\mathrm{CH}_{4}$ $66.5 \%$. Serta untuk lama tinggal bubble 5 detik, prosentase $\mathrm{CO}_{2}$ yang dihasilkan sebesar $6.5 \%$ dan $\mathrm{CH}_{4} 69 \%$.

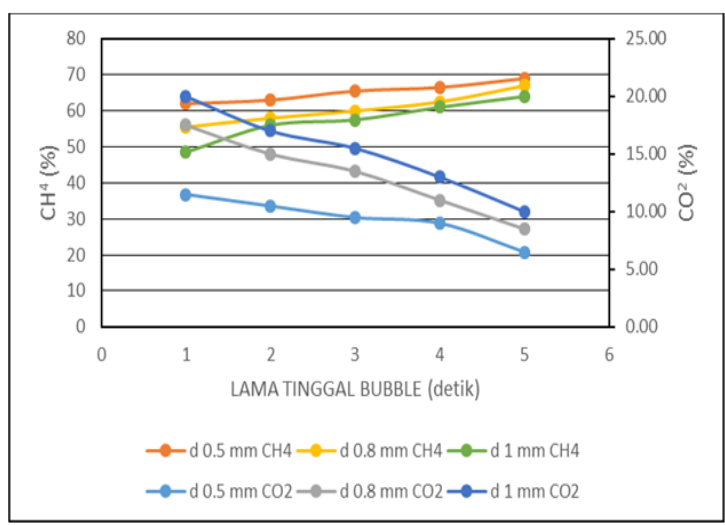

Gambar 7. Grafik hubungan lama tinggal bubble terhadap prosentase $\mathrm{CO}_{2}$ dan $\mathrm{CH}_{4}$ pada biogas dengan variasi lubang bubble generator

Untuk lubang bubble generator d $0.8 \mathrm{~mm}$ dan d $1 \mathrm{~mm}$ dari grafik diatas, dapat diketahui juga semakin lama tinggal bubble prosentase $\mathrm{CO}_{2}$ yang dihasilkan semakin kecil dan semakin lama tinggal bubble prosentase $\mathrm{CH}_{4}$ semakin meningkat. Oleh karena itu prosentase $\mathrm{CO}_{2}$ dalam biogas setelah dilakukan pengujian untuk variasi lubang bubble generator, semakin kecil diameter lubang bubble generator maka prosentase $\mathrm{CO}_{2}$ semakin kecil sedangkan untuk prosentase $\mathrm{CH}_{4}$ semakin meningkat. Dalam penelitian ini diketahui bahwa diameter lubang bubble generator $0.5 \mathrm{~mm}$ dan lama tinggal bubble 5 detik didapatkan hasil yang lebih baik, hal ini didapatkan prosentase $\mathrm{CO}_{2}$ paling kecil adalah $6.5 \%$ dan untuk prosentase $\mathrm{CH}_{4}$ paling besar adalah $69 \%$.

Hubungan debit masuk terhadap prosentase $\mathrm{CO}_{2}$ dan $\mathrm{CH}_{4}$ pada biogas dengan variasi konsentrasi $\mathrm{KOH}$

Dari grafik pada Gambar 8 diketahui untuk variasi konsentrasi $\mathrm{KOH} 0.99 \%$ dan debit masuk $0.3 \mathrm{~m}^{3} / \mathrm{s}$, prosentase $\mathrm{CO}_{2}$ yang dihasilkan sebesar $15.5 \%$ dan $\mathrm{CH}_{4} 57.5 \%$. Sedangkan untuk debit masuk $0.4 \mathrm{~m}^{3} / \mathrm{s}$, prosentase $\mathrm{CO}_{2}$ yang dihasilkan sebesar $18 \%$ dan $\mathrm{CH}_{4} 54 \%$. Untuk debit masuk $0.5 \mathrm{~m}^{3} / \mathrm{s}$, prosentase $\mathrm{CO}_{2}$ yang dihasilkan sebesar $20.5 \%$ dan $\mathrm{CH}_{4} 52.5 \%$. Untuk debit masuk $0.6 \mathrm{~m}^{3} / \mathrm{s}$, prosentase $\mathrm{CO}_{2}$ yang dihasilkan sebesar $24.5 \%$ dan $\mathrm{CH}_{4} 51 \%$. Untuk debit masuk $0.8 \mathrm{~m}^{3} / \mathrm{s}$, prosentase $\mathrm{CO}_{2}$ yang dihasilkan sebesar $25.5 \%$ dan $\mathrm{CH}_{4} 49 \%$.

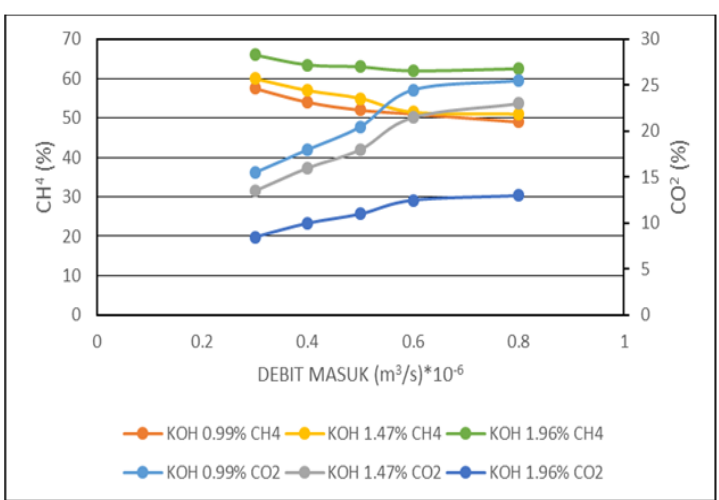

Gambar 8. Grafik hubungan debit masuk terhadap prosentase $\mathrm{CO}_{2}$ dan $\mathrm{CH}_{4}$ pada biogas dengan variasi konsentrasi $\mathrm{KOH}$

Untuk variasi konsentrasi $\mathrm{KOH} 1.47 \%$ dan $\mathrm{KOH} 1.96 \%$ dari grafik diatas, dapat diketahui juga semakin tinggi debit masuk maka prosentase $\mathrm{CO}_{2}$ yang dihasilkan semakin besar dan semakin tinggi debit masuk maka prosentase $\mathrm{CH}_{4}$ semakin kecil. Dalam penelitian ini diketahui bahwa variasi konsentrasi $\mathrm{KOH} 1.96 \%$ dan debit masuk 0.3 $\mathrm{m}^{3} / \mathrm{s}$ didapatkan hasil yang lebih baik, hal ini didapatkan prosentase $\mathrm{CO}_{2}$ paling kecil adalah $8.5 \%$ dan untuk prosentase $\mathrm{CH}_{4}$ paling besar adalah $66 \%$.

Hubungan debit masuk terhadap prosentase $\mathrm{CO}_{2}$ dan $\mathrm{CH}_{4}$ pada biogas dengan variasi lubang bubble generator

Dari Gambar 9 diketahui untuk diameter lubang bubble generator $0.5 \mathrm{~mm}$ dan debit masuk $0.3 \mathrm{~m}^{3} / \mathrm{s}$, prosentase $\mathrm{CO}_{2}$ yang dihasilkan sebesar $10 \%$ dan $\mathrm{CH}_{4}$ yang dihasilkan sebesar 64\%. Sedangkan untuk debit masuk $0.4 \mathrm{~m}^{3} / \mathrm{s}$, prosentase $\mathrm{CO}_{2}$ yang dihasilkan sebesar $12 \%$ dan $\mathrm{CH}_{4} 61.5 \%$. Untuk debit masuk $0.5 \mathrm{~m}^{3} / \mathrm{s}$, prosentase $\mathrm{CO}_{2}$ yang dihasilkan sebesar $13.5 \%$ dan $\mathrm{CH}_{4} 60 \%$. Untuk debit masuk $0.6 \mathrm{~m}^{3} / \mathrm{s}$, prosentase $\mathrm{CO}_{2}$ yang dihasilkan sebesar $20.5 \%$ dan $\mathrm{CH}_{4} 52 \%$. Serta untuk debit masuk $0.8 \mathrm{~m}^{3} / \mathrm{s}$, prosentase $\mathrm{CO}_{2}$ yang dihasilkan sebesar $22 \%$ dan $\mathrm{CH}_{4} 51.5 \%$. 


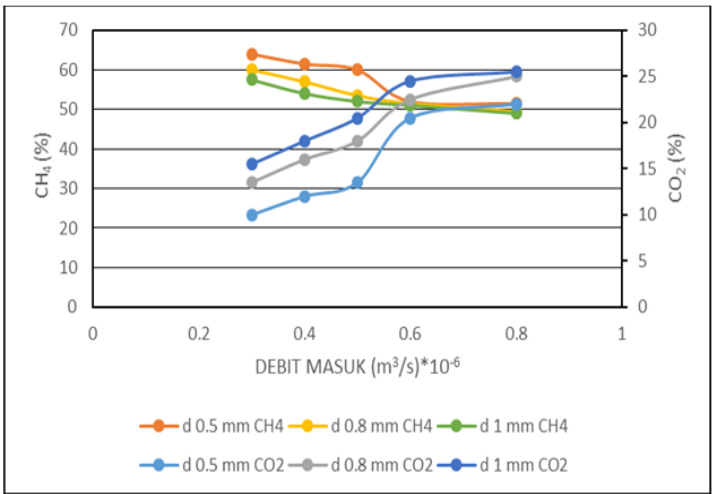

Gambar 9. Grafik hubungan debit masuk terhadap prosentase $\mathrm{CO}_{2}$ dan $\mathrm{CH}_{4}$ pada biogas dengan variasi lubang bubble generator

Untuk lubang bubble generator d $0.8 \mathrm{~mm}$ dan d $1 \mathrm{~mm}$ dari grafik diatas, dapat diketahui juga semakin tinggi debit masuk maka prosentase $\mathrm{CO}_{2}$ yang dihasilkan semakin besar dan semakin tinggi debit masuk maka prosentase $\mathrm{CH}_{4}$ semakin kecil. Dalam penelitian ini diketahui bahwa diameter lubang bubble generator $0.5 \mathrm{~mm}$ dan debit masuk 0.3 $\mathrm{m}^{3} / \mathrm{s}$ didapatkan hasil yang lebih baik, hal ini didapatkan prosentase $\mathrm{CO}_{2}$ paling kecil adalah $10 \%$ dan untuk prosentase $\mathrm{CH}_{4}$ paling besar adalah $64 \%$.
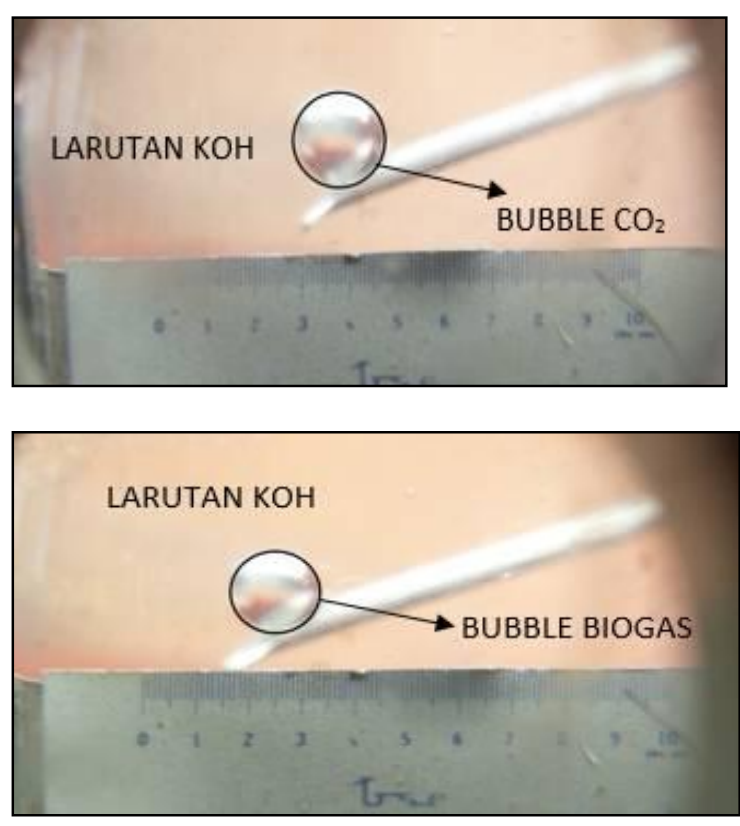

Gambar 10. Bubble tertahan pada larutan $\mathrm{KOH}$
Performansi purifikasi biogas dengan $\mathrm{KOH}$ based absorbent juga dapat diketahui dengan melihat lama tinggal bubble pada larutan $\mathrm{KOH}$ terhadap tinggi larutan, untuk tinggi larutan $1.2 \mathrm{~m}$, lama tinggal bubble selama 5 detik, untuk tinggi larutan $1 \mathrm{~m}$, lama tinggal bubble selama 4 detik, untuk tinggi larutan 0.8 $\mathrm{m}$, lama tinggal bubble selama 3 detik dan untuk tinggi larutan $0.6 \mathrm{~m}$, lama tinggal bubble selama 2 detik. Selain itu, lama bubble tertahan pada pengujian menggunakan $\mathrm{CO}_{2}$ murni adalah 21.38 menit, sedangkan untuk $\mathrm{CH}_{4}$ murni lama bubble tertahan adalah 0 detik, dan untuk biogas lama bubble tertahan adalah 10.38 menit. Bentuk bubble yang tertahan pada larutan $\mathrm{KOH}$ bisa dilihat pada Gambar 10 .

\section{KESIMPULAN}

Setelah dilakukan penelitian dapat ditarik kesimpulan:

1. Semakin tinggi konsentrasi $\mathrm{KOH}$ dan lama tinggal bubblemaka semakin besar prosentase debit terikat yang dihasilkan pada proses penyerapan $\mathrm{CO}_{2}$ murni dan untuk biogas komposisi kandungan $\mathrm{CO}_{2}$ mengalami pengurangan sedangkan $\mathrm{CH}_{4}$ mengalami peningkatan.

2. Semakin kecil diameter lubang bubblegenerator dan lama tinggal bubblemaka semakin besar prosentase debit terikat yang dihasilkan pada proses penyerapan $\mathrm{CO}_{2}$ murni dan untuk biogas komposisi kandungan $\mathrm{CO}_{2}$ mengalami pengurangan sedangkan $\mathrm{CH}_{4}$ mengalami peningkatan.

3. Semakin kecil debit masuk terhadap konsentrasi $\mathrm{KOH}$ dan tinggi larutan maka semakin besar prosentase debit terikat yang dihasilkan pada proses penyerapan $\mathrm{CO}_{2}$ murni dan untuk biogas komposisi kandungan $\mathrm{CO}_{2}$ mengalami pengurangan sedangkan $\mathrm{CH}_{4}$ mengalami peningkatan.

4. Hasil pengujian yang dilakukan didapatkan rata-rata prosentase kandungan $\mathrm{CO}_{2}$ pada biogas semakin berkurang sebesar $27 \%$ dari $35.5 \%$, sedangkan rata-rata prosentase kandungan $\mathrm{CH}_{4}$ pada biogas mengalami peningkatan sebesar $18 \%$ dari $48.5 \%$.

\section{DAFTAR PUSTAKA}

[1] Price,E.C \& Cheremisinoff, P. N, 1981, Biogas Production and Utilization, Ann 
Arbor Science Publishers Inc, United [5] Suriawiria dan Unus, H., 2002. Menuai States of America.

[2] Ryckebosch E., Drouillon M., Vervaeren Biogas dari Limbahhttp://www.pikiranrakyat.com/squirrelmail

H., 2011.Techniques for transformation [6] Purnomo, J. 2009. Rancang Bangun ofbiogas to biomethane, Biomass and Bioenergy, 35, 1633-164.

[3] Fuad Maarif, Januar Arif F, 2009. Absorbsi Gas Karbondioksida $\left(\mathrm{CO}_{2}\right)$ dalam Biogas dengan Larutan $\mathrm{NaOH}$ secara Kontinyu, Universitas Diponegoro Semarang. (Unpublished).

Pembangkit Listrik Tenaga Biogas, Surakarta: Universitas Sebelas Maret.

[7] Sofian, Amat, 2008, Peningkatan kualitas biogas sebagai bahan bakar motor bakar dengan cara pengurangan kadar $\mathrm{CO}_{2}$ dalam biogas dengan menggunakan sulurry $\mathrm{Ca}(\mathrm{OH})_{2}$. Jurusan Teknik Mesin Universitas Muhamaddiah Surakarta. menggunakan zeolit : aplikasi pada pemurnian biogas, Jurnal Dinamika Sains ISSN: 1412-8489, Vol 10, No 22, Universitas Pandanaran, Semarang. 